\title{
Optimalisasi Keterlibatan PKK Dalam Program Kewirausahaan Warga Darmorejo Kota Surabaya
}

\author{
Putri Wulanditya ${ }^{1}$, Kartika Marta Budiana ${ }^{2}$ \\ Universitas Hayam Wuruk Perbanas \\ e-mail: putri@perbanas.ac.id ${ }^{1}, \underline{\text { kartika@ }}$ perbanas.ac.id $^{2}$
}

\begin{abstract}
Abstrak
Warga Darmorejo Kota Surabaya mayoritas masuk dalam kategori ekonomi menengah ke bawah. Rata-rata wanita paruh baya hanya memiliki kesibukan sebagai ibu rumah tangga. Beberapa mempunyai produk industri rumahan yang sederhana dan skala usahanya untuk penduduk sekitar saja. Program pengabdian masyarakat ini bertujuan untuk membantu meningkatkan taraf hidup masyarakat Darmorejo Surabaya dengan memberikan wawasan tentang kewirausahaan. Metode yang digunakan dalam pengabdian ini yaitu memberikan pelatihan kewirausahaan, pendampingan produksi, pelatihan administrasi pembukuan, sampai dengan pendesainan logo produk. Hasil program pengabdian masyarakat antara lain, peningkatan minat berwirausaha, menghasilkan beberapa produk baru, terdapat pencatatan administrasi pembukuan, dan hasil akhir produk berupa bermacam-macam produk unggulan warga Darmorejo.
\end{abstract}

Kata kunci: Kewirausahaan, Pemberdayaan PKK, Produk Unggulan

\section{PENDAHULUAN}

Dalam kehidupan yang semakin berkembang modern, wanita diharapkan dapat mengambil bagian tidak hanya turut mencerdaskan bangsa melalui perannya sebagai ibu dalam rumah tangga. Namun, wanita kini juga dituntut untuk turut membantu perekonomian keluarga dengan memaksimalkan potensi dirinya. Pemberdayaan masyarakat melalui ibu rumah tangga yang terkumpul dalam wadah PKK (Pembinaan Kesejahteraan Keluarga) sangat dibutuhkan dalam mengentaskan kebodohan dan kemiskinan. Pemberdayaan masyarakat bukan sebagai proses pemberian dari pihak yang memiliki sesuatu kepada yang tidak memiliki. Lestari dan Sari (2018) menjelaskan bahwa peran pemberdayaan salah satunya untuk menumbuhkembangkan potensi yang ada pada kelompok yang akan diberdayakan. Pemberdayaan memiliki dua pendekatan yaitu pemberdayaan sebagai sebuah proses dan pemberdayaan sebagai sebuah tujuan. Sebagai proses, pemberdayaan dilihat sebagai serangkaian kegiatan untuk memperkuat keberdayaan atau kemampuan kelompok yang dianggap lemah dalam masyarakat, termasuk individu-individu yang mengalami masalah kemiskinan. Sedangkan apabila dilihat sebagai tujuan, maka pemberdayaan merujuk pada keadaan atau hasil yang ingin dicapai oleh sebuah perubahan sosial. Berdasarkan survei pendahuluan pada daerah Darmorejo Kelurahan Darmo Kecamatan Wonokromo Kota Surabaya, melalui wawancara dengan warga menunjukkan bahwa program pemberdayaan melalui PKK sangat dibutuhkan oleh ibu-ibu di lingkungan tersebut. Ketua RT menggambarkan bagaimana sebenarnya ibu-ibu rumah tangga memiliki minat yang tinggi untuk memiliki usaha sendiri. Namun, mereka terkendala oleh modal yang minim dan skill yang terbatas. Belum pernah ada kegiatan pengabdian yang berasal dari perguruan tinggi yang membantu mereka dalam bidang perekonomian, sebelumnya hanya terbatas pada lingkungan dan kesehatan. PKK di RT 10 RW 4 jalan Darmorejo gang III, ibu-ibunya sangat aktif berkumpul dan selalu mencoba membuat hasil-hasil karya kreatif. Ada beberapa produk yang dihasilkan dan dijual secara individu, tetapi hasilnya tidak maksimal. Ketua RT menginginkan warga Darmorejo memiliki keunggulan produk yang bisa dikenal oleh masyarakat Surabaya dan nantinya juga untuk skala nasional. Warga sudah menciptakan brand bersama yaitu D'Craft. Namun, belum ada produk yang diberi label tersebut sebagai produk unggulan bersama. Latar belakang permasalahan tersebut kemudian dijadikan landasan untuk merancang program pengabdian pada masayarakat ini. Dengan demikian, tujuan program pengabdian ini secara umum adalah meningkatkan taraf hidup masyarakat Darmorejo Surabaya dengan memberikan wawasan tentang kewirausahaan. Tujuan khususnya antara lain: (1) Memberikan pengetahuan tentang kewirausahaan bagi masyarakat yang telah memiliki produk maupun yang berminat untuk menjadi wirausaha, (2) Melakukan pendampingan untuk menghasilkan produk-produk baru yang ramah lingkungan dan layak jual, (3) Membantu ibu-ibu PKK yang telah memiliki produk 
untuk mulai membuat administrasi atau pembukuan keuangan usaha dan (4) Mendesainkan label untuk macam-macam produk ibu-ibu PKK menjadi satu ciri khas brand warga Darmorejo. Program pengabdian kepada masyarakat yang diselenggarakan oleh Tim Dosen STIE Perbanas Surabaya pada Ibu PKK Warga Darmorejo Kota Surabaya diharapkan dapat menciptakan jalinan kerjasama yang sinergis antara pihak kampus dengan lingkungan masyarakat. Tambahan wawasan ilmu pengetahuan yang bersumber dari lembaga pendidikan khususnya perguruan tinggi dapat diperoleh masyarakat. Selain itu juga, masyarakat memiliki wadah konsultasi mengenai kewirausahaan, sehingga kesulitan atau kendala yang dihadapi dapat terselesaikan.

\section{METODE PENGABDIAN}

Pelaksanaan kegiatan masyarakat dilakukan melalui dua metode, yaitu pelatihan dan pendampingan. Metode pelatihan dilakukan untuk menambah wawasan kewirausahaan dan memberikan pemahaman tentang administrasi pembukuan. Metode pendampingan dilakukan saat pembuatan produk, pemilihan kemasan, dan pendesainan logo produk. Sasaran pengabdian kepada masyarakat untuk program ini adalah ibu-ibu PKK di area RT 10 RW 4 Kelurahan Darmo Kecamatan Wonokromo Kota Surabaya maupun ibu-ibu di lingkungan sekitar yang berminat untuk mengikuti kegiatan.

\section{HASIL DAN PEMBAHASAN}

Berikut ini tahapan pelaksanaan program pengabdian masyarakat:

\section{a. Pelatihan Kewirausahaan Kegiatan}

pelatihan kewirausahaan telah diselenggarakan selama 2,5 jam dengan jumlah peserta 22 orang yang merupakan ibu-ibu PKK dari lingkup RW 4 Kelurahan Darmo. Narasumber dari pelatihan ini adalah Ibu Drs. Aniek Maschudah., M.Si. Narasumber adalah dosen Kewirausahaan di STIE Perbanas Surabaya dan Reviewer PKM DIKTI. Tempat pelaksanaan di Balai PAUD RW 4 Kelurahan Darmo. Selain tim pelaksana kegiatan abdimas, kegiatan ini juga dihadiri oleh Bapak \& Ibu RT setempat dan Kepala Bidang Pengabdian Masyarakat Pusat Penelitian dan Pengabdian Masyarakat STIE Perbanas Surabaya. engikuti kegiatan.

Tim pengabdian terlibat sebagai panitia pelaksana dengan pengisi materi diambil dari luar tim. Adapun kegiatan terdiri dari ice breaking, sambutan, pemaparan materi kewirausahaan, dan diakhiri dengan diskusi tanya jawab
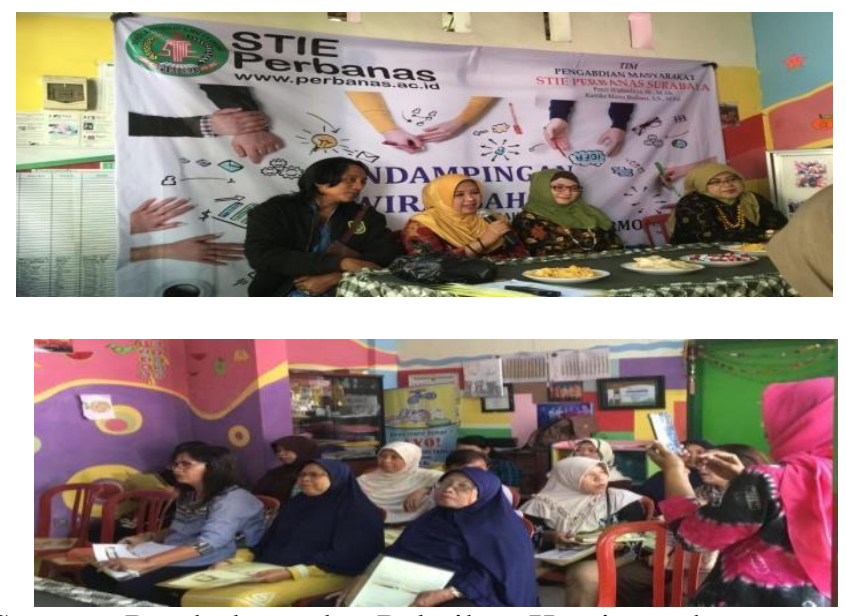

Gambar 1. Suasana Pembukaan dan Pelatihan Kewirausahaan

Pada gambar 1 tersebut, dari kiri ke kanan yaitu Bapak Ketua RT 10 Kelurahan Darmo, Kepala Bidang Pengabdian Masyarakat PPPM STIE Perbanas Surabaya, Ketua Tim Pelaksana Pengabdian Masyarakat dan Narasumber Pelatihan. Sambutan diawali oleh Bapak Ketua RT dan diakhiri oleh Ketua Tim Pelaksana Abdimas. Indikator keberhasilan tercapai sesuai target minimumdan peserta terlihat antusias mengikuti kegiatan. Hal ini terlihat seperti pada gambar.

\section{b. Pendampingan Proses Produksi}

Kegiatan pendampingan proses produksi telah diselenggarakan selama 3 jam yang diikuti oleh 10 orang ibu-ibu PKK dari lingkup RT 10 Kelurahan Darmo. Tempat 
pelaksanaan di GangDarmorejo III, karena pelaksanan malam hari dan mereka biasanya melaksanaan kegiatan kumpul di jalan kampung tersebut. Kegiatan yang dilakukan berupa pembuatan produk daur ulang sabun dari minyak jelantah dijadikan bentuk bunga hias dan sabun batang, produk manik jadi dompet, danproduk tas dari rajutan tangan.

Dalam kegiatan tersebut, tim terlibat langsung ikut mendampingi dan membuat produk. Daripendampingan awal tersebut, ibu-ibu diminta untuk mengkreasikan produknya masingmasing berdasarkan minat dan kemampuan mereka. Indikator keberhasilan tercapai sesuai target yaitu, terciptanya produk baru sebagai pemicu semangat ibu-ibu minimal 3 produk.

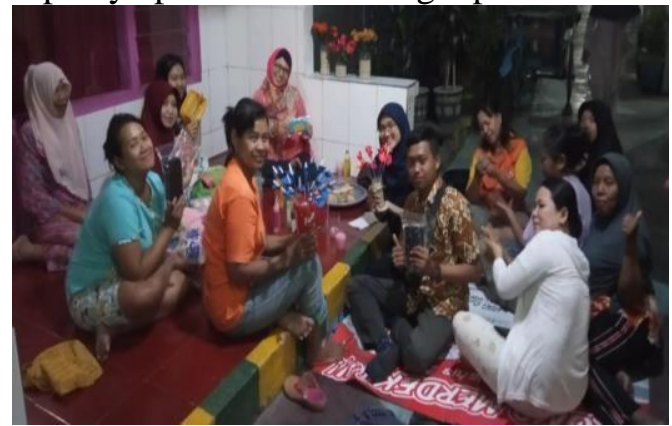

Gambar 2. Pendampingan Pembuatan Produk

Pada gambar 2 terlihat Ibu-Ibu PKK dibantu dengan tim pelaksana abdimas dalam pembuatanproduk. Produk yang ditunjukan adalah sabun dari minyak jelantah, gel air untuk vas dan kerajinanronce untuk dompet dan tas.

\section{a. Pelatihan Pembukuan}

Kegiatan pelatihan pembukuan telah diselenggarakan selama 2 jam dengan peserta sebanyak 16 orang yang merupakan Ibu-ibu PKK RT 10 Kelurahan Darmo. Tempat pelaksanaan masih di Gang Darmorejo III. Tim pengabdian memberikan materi tentang bagaimana melakukan administrasi pengeluaran dan pemasukan jika memproduksi suatu barang.

Pada kegiatan tersebut, ibu-ibu diminta juga langsung mempraktekkan bagi yang sebelumnyasudah punya usaha sendiri. Kegiatan terlaksana sesuai target. Masing-masing melanjutkan sendiri untuk pembukuan usahanya dan diseragamkan untuk bukunya. Sehingga PKK RT memiliki catatanyang rapi untuk setiap usaha yang dilakukan.

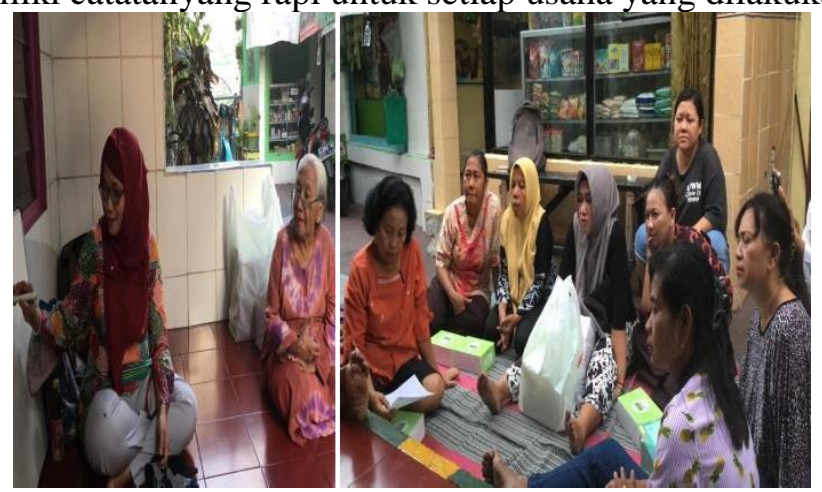

Gambar 3. Pelatihan Pembukuan

Pada gambar 3 terlihat Ibu-Ibu PKK sedang mendengarkan pengarahan mengenai pembukuansederhana dari ketua tim pelaksana pengabdian masyarakat. Dengan tempat di salah satu teras wargakegiatan ini dilakukan. Media yang digunakan pada saat pelatihan adalah papan tulis sederhana. Hampir dua puluh Ibu-Ibu datang untuk mengikuti pendampingan ini.

\section{b. Pendampingan Kemasan Produk}

Kegiatan ini dilakukan beberapa kali karena mengikuti waktu kosong ibu-ibu. Pendampingan juga dilakukan secara online (melalui whatsup) untuk mendikusikan kemasan yang cocok dan menarik. Pada program pendampingan ini, tim juga terlibat mendesainkan logo produk-produk yangdihasilkan oleh Ibu-ibu PKK RT 10 Kelurahan Darmorejo III, karena pelaksanan malam hari dan mereka biasanya melaksanaan kegiatan kumpul di jalan kampung tersebut. Kegiatan yang dilakukan berupa pembuatan produk daur ulang sabun dari minyak jelantah dijadikan 
bentuk bunga hias dan sabun batang, produk manik jadi dompet, danproduk tas dari rajutan tangan.

Dalam kegiatan tersebut, tim terlibat langsung ikut mendampingi dan membuat produk. Daripendampingan awal tersebut, ibu-ibu diminta untuk mengkreasikan produknya masingmasing berdasarkan minat dan kemampuan mereka. Indikator keberhasilan tercapai sesuai target yaitu, terciptanya produk baru sebagai pemicu semangat ibu-ibu minimal 3 produk.

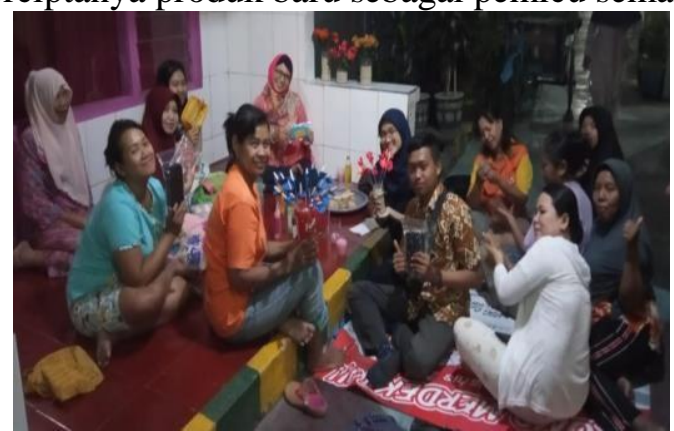

Gambar 2. Pendampingan Pembuatan Produk

Pada gambar 2 terlihat Ibu-Ibu PKK dibantu dengan tim pelaksana abdimas dalam pembuatanproduk. Produk yang ditunjukan adalah sabun dari minyak jelantah, gel air untuk vas dan kerajinanronce untuk dompet dan tas.

\section{c. Pelatihan Pembukuan}

Kegiatan pelatihan pembukuan telah diselenggarakan selama 2 jam dengan peserta sebanyak 16 orang yang merupakan Ibu-ibu PKK RT 10 Kelurahan Darmo. Tempat pelaksanaan masih di Gang Darmorejo III. Tim pengabdian memberikan materi tentang bagaimana melakukan administrasi pengeluaran dan pemasukan jika memproduksi suatu barang.

Pada kegiatan tersebut, ibu-ibu diminta juga langsung mempraktekkan bagi yang sebelumnyasudah punya usaha sendiri. Kegiatan terlaksana sesuai target. Masing-masing melanjutkan sendiri untuk pembukuan usahanya dan diseragamkan untuk bukunya. Sehingga PKK RT memiliki catatanyang rapi untuk setiap usaha yang dilakukan.

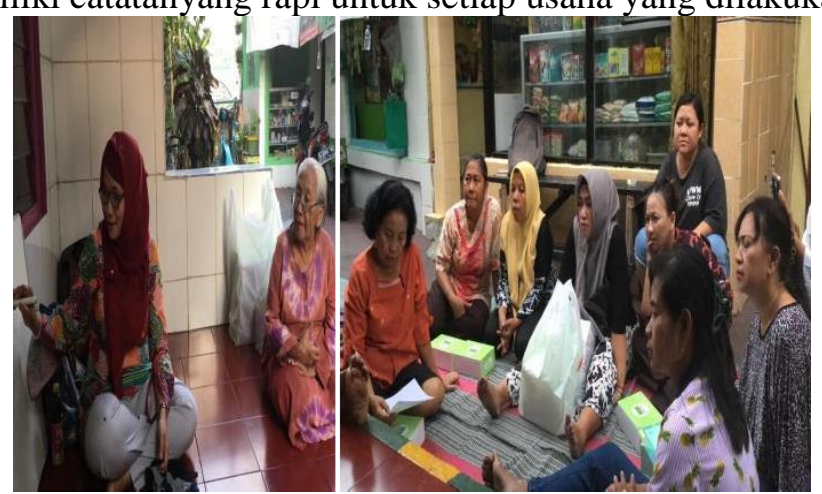

Gambar 3. Pelatihan Pembukuan

Pada gambar 3 terlihat Ibu-Ibu PKK sedang mendengarkan pengarahan mengenai pembukuansederhana dari ketua tim pelaksana pengabdian masyarakat. Dengan tempat di salah satu teras wargakegiatan ini dilakukan. Media yang digunakan pada saat pelatihan adalah papan tulis sederhana. Hampir dua puluh Ibu-Ibu datang untuk mengikuti pendampingan ini.

\section{d. Pendampingan Kemasan Produk}

Kegiatan ini dilakukan beberapa kali karena mengikuti waktu kosong ibu-ibu. Pendampinganjuga dilakukan secara online (melalui whatsup) untuk mendikusikan kemasan yang cocok dan menarik. Pada program pendampingan ini, tim juga terlibat mendesainkan logo produk-produk yangdihasilkan oleh Ibu-ibu PKK RT 10 Kelurahan Darmo. Target melebihi harapan, produk-produk yang dihasilkan beragam antara lain: peyek, bumbu pecel, dompet manik, magic crystal, sabun minyak jelantah, sirup alang-alang dan jeruk nipis, aneka sambel (bawang, teri, klotok). 

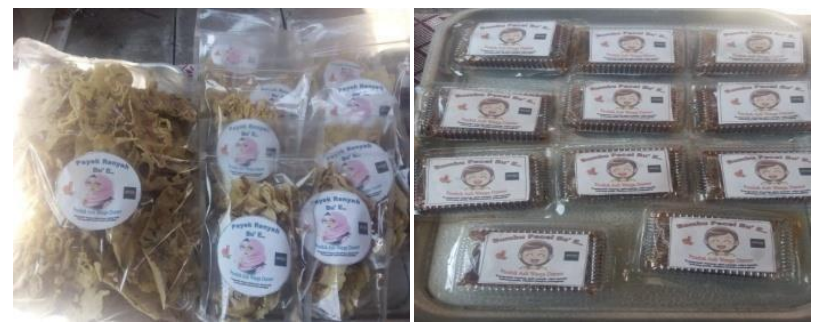

Gambar 4. Contoh Desain Produk

Pada gambar 4 terdapat macam-macam produk para Ibu-Ibu PKK RT 10 Keluarahan Darmorejo yang telah memiliki logo sederhana. Pada logo ini terdapat judul produk dan pembuat produk. Logo ini dapat terwujud atas bantuan tim pelaksana pengabdian masyarakat yang mendampingi hingga pencetakan logo produk.

\section{e. Pendampingan dalam SSC}

Kegiatan ini merupakan kegiatan tambahan diluar rencana, yaitu pendampingan dalam rangkapenilaian SSC (Surabaya Smart City). Ibu-ibu PKK menghendaki tim untuk dapat membantu mempersiapkan penjurian terhadap RT mereka yang saat itu sedang membutuhkan pendampingan. Pada saat pelaksanaan Tim pengabdian membantu menjawab pertanyaan dari Tim juri SSC terkait produk, pembukuan, dan kerjasama RT dengan pihak STIE Perbanas Surabaya. Juri Lomba Smart City yang datang berkunjung terdiri dari petugas Kelurahan, Pemerintahan Kota Surabaya, Dosen Universitas Negeri dan jurnalis. Seperti terlihat pada gambar 5, tim pelaksana pengabdian masyarakat berfoto dengan Juri Lomba Surabaya Smart City dan peserta kegiatan lomba dari wargasetempat.

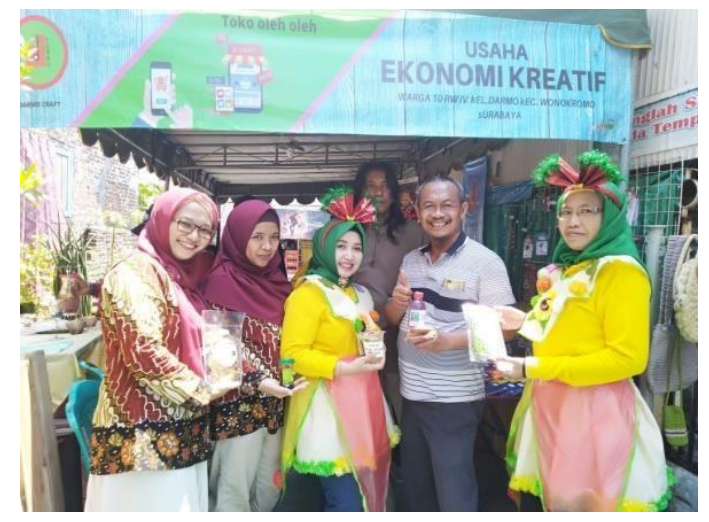

Gambar 5. Kegiatan Penjurian SSC

Kegiatan pengabdian masyarakat hasil kerjasama tim Dosen dan mahasiswa STIE Perbanas Surabaya dengan warga RT 10 RW 4 Kelurahan Darmo Kecamatan Wonokromo Kota Surabaya yang telah dilakukan tersaji pada tabel 1. Berdasarkan analisis kegiatan, seluruh program kegiatan pengabdian telah mencapai sasaran yaitu (1) memberikan pengetahuan tentang kewirausahaan bagimasyarakat yang telah memiliki produk maupun yang berminat untuk menjadi wirausaha, (2) membantu ibu-ibu PKK yang telah memiliki produk untuk mulai membuat administrasi atau pembukuan keuangan usaha, (3) melakukan pendampingan untuk menghasilkan produk-produk baru yang ramah lingkungan dan layak jual, dan (4) mendesainkan label untuk macam-macam produk ibu-ibu PKK menjadi ciri khas brand warga Darmorejo.

Tabel 1. Analisis Hasil Program Pengabdian Masyarakat

\begin{tabular}{|l|l|l|}
\hline Permasalahan & Program & Pencapaian \\
\hline $\begin{array}{l}\text { Ingin memahami tentang } \\
\text { bagaimana berwirausaha }\end{array}$ & $\begin{array}{l}\text { Pelatihan } \\
\text { kewirausahaan }\end{array}$ & $\begin{array}{l}\text { Bertambahnya ibu-ibu PKK yang } \\
\text { berani berwirausaha }\end{array}$ \\
\hline
\end{tabular}




\begin{tabular}{|l|l|l|}
\hline Produk ibu-ibu masih terbatas & $\begin{array}{l}\text { Pendampingan } \\
\text { produksi }\end{array}$ & $\begin{array}{l}\text { Menghasilkan produk bermacam- } \\
\text { macam }\end{array}$ \\
\hline Belum ada pencatatan pembukuan & $\begin{array}{l}\text { Pelatihan } \\
\text { pembukuan }\end{array}$ & $\begin{array}{l}\text { Sudah ada buku administrasi untuk } \\
\text { setiap usaha }\end{array}$ \\
\hline $\begin{array}{l}\text { Kemasan seadanya dan belum } \\
\text { berlogo }\end{array}$ & $\begin{array}{l}\text { Pendampingan } \\
\text { kemasan }\end{array}$ & $\begin{array}{l}\text { Semua produk unggulan RT telah } \\
\text { memiliki logo }\end{array}$ \\
\hline
\end{tabular}

Pencapaian tujuan program dilakukan dengan berbagai upaya yang telah dilakukan oleh Timpengabdian melalui koordinasi yang baik antara Tim, Ketua RT, dan perwakilan ibu PKK. Adapuncapaian tambahan dengan dilaksanakannya kegiatan pengabdian masyarakat ini adalah hasil pendampingan pada Surabaya Smart City lingkungan RW mereka meraih prestasi sebagai 150 RT terbaik se-Surabaya.

Hasil kegiatan pengabdian masyarakat berupa pelatihan dan pendampingan ini, diharapkandapat dilanjutkan secara mandiri oleh warga RT 10 khususnya produk-produk yang dihasilkan ibu-ibu PKK walaupun program telah selesai dilaksanakan. Dengan demikian, adanya kegiatan pengabdian masyarakat ini dapat menjadikan warga binaan yang produktif dan kreatif. Jalinan kerjasama juga dapat secara berkelanjutan diharapkan terus berlangsung, sehingga dapat mewujudkan misi STIE Perbanas Surabaya dalam melaksanakan tridharma Perguruan Tinggi melalui kegiatan pengabdian masyarat.

\section{SIMPULAN}

Berdasarkan uraian berbagai pelaksanaan kegiatan pengabdian masyarakat yang telah diselenggarakan, maka seluruhnya telah menjawab permasalahan yang dihadapi oleh mitra yaitu ibu PKK warga Darmorejo kota Surabaya. Kondisi ibu PKK sebelum program pengabdian ini tidak memiliki wawasan kewirausahaan, mengalami kebingungan tentang kreasi produk, pembukuan usaha, sampai dengan kemasan produk yang menarik. Setelah program ini terlaksana, kondisi mitra telah memiliki keberanian berwirausaha, terbukti bertambahnya jumlah ibu PKK yang mampu menghasilkan produk layak jual. Berakhirnya program ini juga menghasilkan bauran produk yang menjadi keunggulan warga Darmorejo.

\section{SARAN}

Logo yang didesainkan oleh Tim masih sederhana, belum mencantumkan secara lengkap komposisi yang lengkap seperti komposisi produk, batas pemakaian atau konsumsi produk (expired date), maupun pendftaran sebagai merek dagang. Sehingga Tim menyarankan untuk kedepannya, warga yang telah memiliki produk dapat mengikuti program pengembangan ekonomi kreatif yang disediakan secara free (gratis) oleh Pemerintah Kota Surabaya untuk pendaftaran merek dagang dan pendampingan yang lebih intensif lagi.

\section{UCAPAN TERIMA KASIH}

Terima kasih kepada pihak-pihak yang telah mendukung program pengabdian masyarakatini, sehingga terlaksana dengan baik dan lancar : segenap warga, Pengurus PKK, dan Ketua RT 10RW 4 kelurahan Darmo kecamatan Wonokromo kota Surabaya, narasumber materi kewirausahaan(Dra. Ec. Aniek Maschudah I.), maupun Kepala Unit Pengabdian Masyarakat (Dr. Dra. Diah Ekaningtias, Ak., MM.) STIE Perbanas Surabaya beserta timnya.

\section{DAFTAR PUSTAKA}

Gunawan, A. 2019, Pemberdayaan ibu-ibu PKK dalam menumbuhkan jiwa kewirausahaan melalui pelatihan pembuatan chicken nugget di desa Ridogalih kabupaten Bekasi, Loyalitas: Jurnal Pengabdian Kepada Masyarakat, 2(1), 124-133.

Kasali, R., dkk. 2010, Modul Kewirausahaan untuk Program Strata 1, PT. Mizan Publika, Jakarta.

Lestari, A. F \& Sari, I. P. 2018, Kelor (kelas entrepreneurship pemanfaatan daun kelor) sebagaiupaya pemberdayaan untuk meningkatkan produktivitas ibu rumah tangga, Jurnal Kesmas Untika Luwuk, 9(2), 1429-1444. 